\title{
Three new species of Echinobothrium (Cestoda: Diphyllidea) from Indo-Pacific stingrays of the genus Pastinachus (Rajiformes: Dasyatidae)
}

\author{
Roman Kuchta ${ }^{1}$ and Janine N. Caira ${ }^{2}$ \\ ${ }^{1}$ Institute of Parasitology, Biology Centre of the Academy of Sciences of the Czech Republic and Faculty of Science, University of \\ South Bohemia, Branišovská 31, 37005 České Budějovice, Czech Republic; \\ ${ }^{2}$ Department of Ecology \& Evolutionary Biology, University of Connecticut, 75 N. Eagleville Rd., Storrs, Connecticut 06269- \\ 3043, USA
}

\begin{abstract}
Three new species of diphyllidean cestodes are described from stingrays of the genus Pastinachus from the Indian and Pacific Oceans. All three new species differ from all but 10 of the 36 valid species of Echinobothrium van Beneden, 1849 in that they bear lateral hooklets arranged in a continuous band across each lateral surface of the rostellum joining the groups of dorsal and ventral apical hooks, rather than arranged in distinct dorsal and ventral groups, on each side of the apical hooks. Echinobothrium nataliae sp. n. ex Pastinachus solocirostris off Borneo differs from other relatives in the following combination of characters: number of spines in each column on the cephalic peduncle, number of lateral hooklets and number of apical hooks. Echinobothrium reginae sp. n. ex Pastinachus cf. sephen off Madagascar differs from all congeners in the following combination of characters: number of hooklets and number of spines on the cephalic peduncle. Echinobothrium vojtai sp. n. from an undescribed species of Pastinachus off Borneo differs from its congeners in the following combination of characters: number of hooklets, number of apical hooks and number of spines in each column on the cephalic peduncle. The hook formula was modified to accommodate species with lateral hooklets arranged in a continuous band as follows: $\{(\mathrm{LH}) \mathrm{AH}(\mathrm{A}) / \mathrm{AH}(\mathrm{B})\}$, where $(\mathrm{LH})$ is the total number of lateral hooklets in a band. A table of all nominal species of Echinobothrium, showing their taxonomic status, type host and locality, number of peduncle spines in a column and hook formula, is presented. Macrobothridium djeddensis and Macrobothridium sinensis are transferred to Echinobothrium. In addition, Echinobothrium deeghai is considered as a species inquirenda.
\end{abstract}

Keywords: Borneo, Echinobothrium nataliae, Echinobothrium reginae, Echinobothrium vojtai, hook formula, Madagascar, Macrobothridium

Tapeworms belonging to the order Diphyllidea van Beneden in Carus, 1863 comprise a unique and small group of parasites of elasmobranchs. While the phylogenetic position of the order remains somewhat unclear, it is likely most closely related to the order Trypanorhyncha Diesing, 1863 (see Palm et al. 2009, Olson et al. 2010). To date, the order is considered to include 47 nominal species in two genera. The third nominal genus, Macrobothridium Khalil et Abdul-Salam, 1989, was synonymised with Echinobothrium van Beneden, 1849 by Tyler (2006). Here we follow Tyler (2006) and thus formally transfer both Macrobothridium djeddensis Pramanik et Manna, 2005 of Pramanik and Manna (2005) ex Rhynchobatus djiddensis (Forsskål) and Macrobothridium sinensis Li et Wang, 2007 of Li and Wang (2007) ex Platyrhina sinensis (Bloch and Schneider) to Echinobothrium, creating the new combinations Echinobothrium djeddensis comb. n. and Echinobothrium sinensis comb. n.
While some species are known from sharks (e.g., Echinobothrium diamanti Ivanov et Lipshitz, 2006), the majority of Echinobothrium species are parasites of batoids, having been reported from a diversity of genera (Ivanov and Lipshitz 2006, Tyler, 2006; Table 1). The three new species described below represent the first verified records of diphyllideans from cowtail stingrays of the genus Pastinachus Rüppell and also expand the known distribution of Echinobothrium spp. to include the island of Madagascar.

\section{MATERIALS AND METHODS}

In total, 13 stingrays belonging to three species of the genus Pastinachus Rüppell were dissected. These included a total of 9 specimens of Pastinachus solocirostris Last, Manjaji et Yearsley, from the island of Borneo, 7 of which were collected between May 2002 and April 2004 from the South China Sea in Malaysian Borneo as follows: 1 specimen (BO-11)

Address for correspondence: R. Kuchta, Institute of Parasitology, Biology Centre of the Academy of Sciences of the Czech Republic, Branišovská 31, 37005 České Budějovice, Czech Republic. Phone: +420 38777 5432; Fax: +420 38531 0388; E-mail: krtek@paru.cas.cz 
off Santubong $\left(01^{\circ} 43^{\prime} 00.16^{\prime \prime} \mathrm{N}, 110^{\circ} 19^{\prime} 13.55^{\prime \prime} \mathrm{E}\right), 3$ specimens (BO-164, BO-165, BO-177) off Semantan $\left(01^{\circ} 48^{\prime} 15^{\prime \prime} \mathrm{N}\right.$, $109^{\circ} 46^{\prime} 47^{\prime \prime} \mathrm{E}$ ), and 3 specimens (BO-256, BO-267, BO$464)$ off Mukah $\left(02^{\circ} 53^{\prime} 52^{\prime \prime} \mathrm{N}, 112^{\circ} 05^{\prime} 44^{\prime \prime} \mathrm{E}\right)$. The remaining 2 specimens from Borneo were collected from Indonesian localities (i.e., off Kalimantan) between November 2006 and July 2007 as follows: 1 specimen (KA-44) from Muara Pasir $\left(01^{\circ} 45^{\prime} 58^{\prime \prime} \mathrm{S}, 116^{\circ} 23^{\prime} 36^{\prime \prime} \mathrm{E}\right)$ and 1 specimen (KA-148) from Singkawang $\left(00^{\circ} 55^{\prime} 06^{\prime \prime} \mathrm{N}, 108^{\circ} 58^{\prime} 58^{\prime \prime} \mathrm{E}\right)$. Two specimens (GA16, GA-31), identified as Pastinachus cf. sephen (see Jensen and Caira 2008) were collected in September 1999 off La Mer d'Emeraude near Ramena (12 $\left.11^{\prime} 60^{\prime \prime} \mathrm{S}, 4^{\circ} 22^{\prime} 00^{\prime \prime} \mathrm{E}\right)$ and out of Nosy Be $\left(13^{\circ} 25^{\prime} \mathrm{S}, 48^{\circ} 6^{\prime} \mathrm{E}\right)$, Madagascar. Finally, two specimens from an undescribed species of Pastinachus, which will be referred to here as Pastinachus sp. (thin-tail), were examined. These specimens were collected in May 2003 from the South China Sea, in Malaysian Borneo off Kampung Tetabuan $\left(06^{\circ} 01^{\prime} 10^{\prime \prime} \mathrm{N}, 117^{\circ} 42^{\prime} 15^{\prime \prime} \mathrm{E}\right)$ (BO-99) and in July 2007 off Selakau $\left(01^{\circ} 03^{\prime} 31^{\prime \prime} \mathrm{N}, 108^{\circ} 58^{\prime} 25^{\prime \prime} \mathrm{E}\right)$ in Kalimantan (KA-162). With the exception of the hosts from Madagascar, all hosts were caught using small bottom trawls or small-mesh gill nets in conjunction with local fishermen. The specimens from Madagascar were collected using a hand spear. In each case, the spiral intestine was removed, opened with a longitudinal midventral incision extending to the centre of the lumen of the spiral intestine to expose the upper and lower surfaces of each chamber, and fixed in $10 \%$ formalin in the field. Spiral intestines were transported to the lab in individual whirl-pak bags and were subsequently transferred to $70 \%$ ethanol for storage.

Tapeworms were prepared as whole mounts for light microscopy as follows. They were hydrated in a graded ethanol series, stained in Delafield's haematoxylin, differentiated in tap water, destained in acidic $70 \%$ ethanol, neutralized in basic $70 \%$ ethanol, dehydrated in a graded ethanol series, cleared in methyl salicylate, and mounted on glass slides in Canada balsam. Compressed mounts of rostellar hooks and peduncle spines were prepared as follows. Specimens were hydrated in a graded ethanol series, compressed and transferred to Berlese's medium and subsequently mounted in Canada balsam on glass slides. Semi-permanent mounts of eggs were prepared using the lacto-phenol method described by Jensen (2005). Measurements were acquired using an optical reticle or with a SPOT Diagnostic Instrument digital camera system mounted on a Zeiss Axioskop 2 and SPOT software (version 4.5). Hook terminology, numbering scheme and measurements follow Tyler (2006). The hook formula presented is modified from that of Neifar et al. (2001) to more readily accommodate species with continuous bands of lateral hooklets. The modified formula is as follows: $\{(\mathrm{LH}) \mathrm{AH}(\mathrm{A}) / \mathrm{AH}(\mathrm{B})\}$, where $(\mathrm{LH})$ is the total number of lateral hooklets in a band on one side. A more detailed description of the scheme is presented in the Discussion below. Measurements are given in the text as ranges followed in parentheses by the mean, standard deviation, and number of measurements made. All measurements are in micrometres unless otherwise noted. Microthrix terminology follows Chervy (2009).

Samples were prepared for scanning electron microscopy (SEM) as follows. They were hydrated in a graded ethanol series, transferred to $1 \%$ osmium tetroxide overnight, dehydrated in a graded ethanol series, transferred to hexamethyldisilazane (HMDS) (Ted Pella, Inc., Redding, California), and allowed to air dry. They were subsequently mounted on aluminium stubs using double-sided carbon tape, sputter coated with 30-nm gold/ palladium, and examined with a LEO/Zeiss DSM982 Gemini field emission scanning electron microscope.

Museum abbreviations used are as follows: IPCAS, Institute of Parasitology, Biology Centre of the Academy of Sciences of the Czech Republic, České Budějovice, Czech Republic; LRP, Lawrence R. Penner Parasitology Collection, Department of Ecology and Evolutionary Biology, University of Connecticut, Storrs, Connecticut; MNHN, Muséum National d'Histoire Naturelle, Paris, France; MZB, Museum Zoologicum Bogoriense, Zoological Division, Research Center for Biology, Indonesian Institute of Science, Cibinong, Indonesia; MZUM(P) Muzium Zoologi, Universiti Malaya, Kuala Lumpur, Malaysia; SBC, Sarawak Biodiversity Center, Kuching, Sarawak, Malaysia; and USNPC, U.S. National Parasite Collection, Beltsville, Maryland.

For comparative purposes, the following material of species of Echinobothrium was examined: 1 paratype of E. bonasum Williams et Campbell, 1980 (LRP No. 7442); 3 whole mount vouchers (LRP Nos. 7443-7445) and 1 apical hook preparation of voucher of E. fautleyae Tyler et Caira, 1999 (LRP No. 7446); 4 whole mounts of vouchers (LRP Nos. 7447-7448) of E. mexicanum Tyler et Caira, 1999; 12 paratypes of E. hoffmanorum Tyler, 2001 (LRP Nos. 2038-2050); and 22 paratypes of E. rayallemangi Tyler, 2001 (LRP Nos. 2000-2021).

\section{RESULTS}

Echinobothrium nataliae sp. n. Figs. 1, 4-8, 19-26

Description (based on whole mounts of 12 mature worms, 2 compressed scoleces, semi-permanent mount of 1 gravid proglottid in lactophenol and 5 specimens examined with SEM): Worms euapolytic, 1,714-3,098 $(2,427 \pm 426 ; 10)$ long; greatest width at level of terminal proglottid, $150-374(246 \pm 62 ; 10)$ wide; proglottids acraspedote, 6-7 in number (Fig. 1). Scolex consisting of scolex proper and cephalic peduncle (Figs. 1, 4, 19). Scolex proper $205-251(227 \pm 12 ; 10)$ long by $160-206$ $(185 \pm 15 ; 10)$ wide, composed of armed apical rostellum and 1 dorsal and 1 ventral bothrium; bothria 146-187 $(166 \pm 12 ; 10)$ long by $159-206(183 \pm 16 ; 10)$ wide. Rostellum bearing 1 dorsal and 1 ventral group of 27-29 $(28.5 \pm 1 ; 7)$ solid apical hooks arranged in 2 rows flanked on each side by continuous band of 10-14 $(13.5 \pm 2 ; 7)$ small lateral hooklets; hooklets $18-34$ (22 \pm 3 ; 34) long, with scalpel-like blade (Figs. 5, 26). Hook formula $\{(10$ 14) $14 / 13-15\}$. Apical hooks gradually increasing in length towards centre of group, type B symmetry. First B hook after hooklets $30-36(35 \pm 7 ; 4)$ long $(18-30 \%$ longer than adjacent hooklet), remaining B hooks 49-110 long $(88 \pm 19 ; 32)$; first A hook after first B hook 34-52 (42 $\pm 8 ; 5)$ long (4-5\% longer than first B hook), remaining A hooks 50-118 $(89 \pm 19 ; 30)$ long. Cephalic peduncle $280-469(386 \pm 61 ; 10)$ long by $66-108$ (95 \pm 17 ; 10) wide, armed with 8 longitudinal columns of 24-29 $(28 \pm 2 ; 24)$ spines; spines with triradiate bases, decreas- 


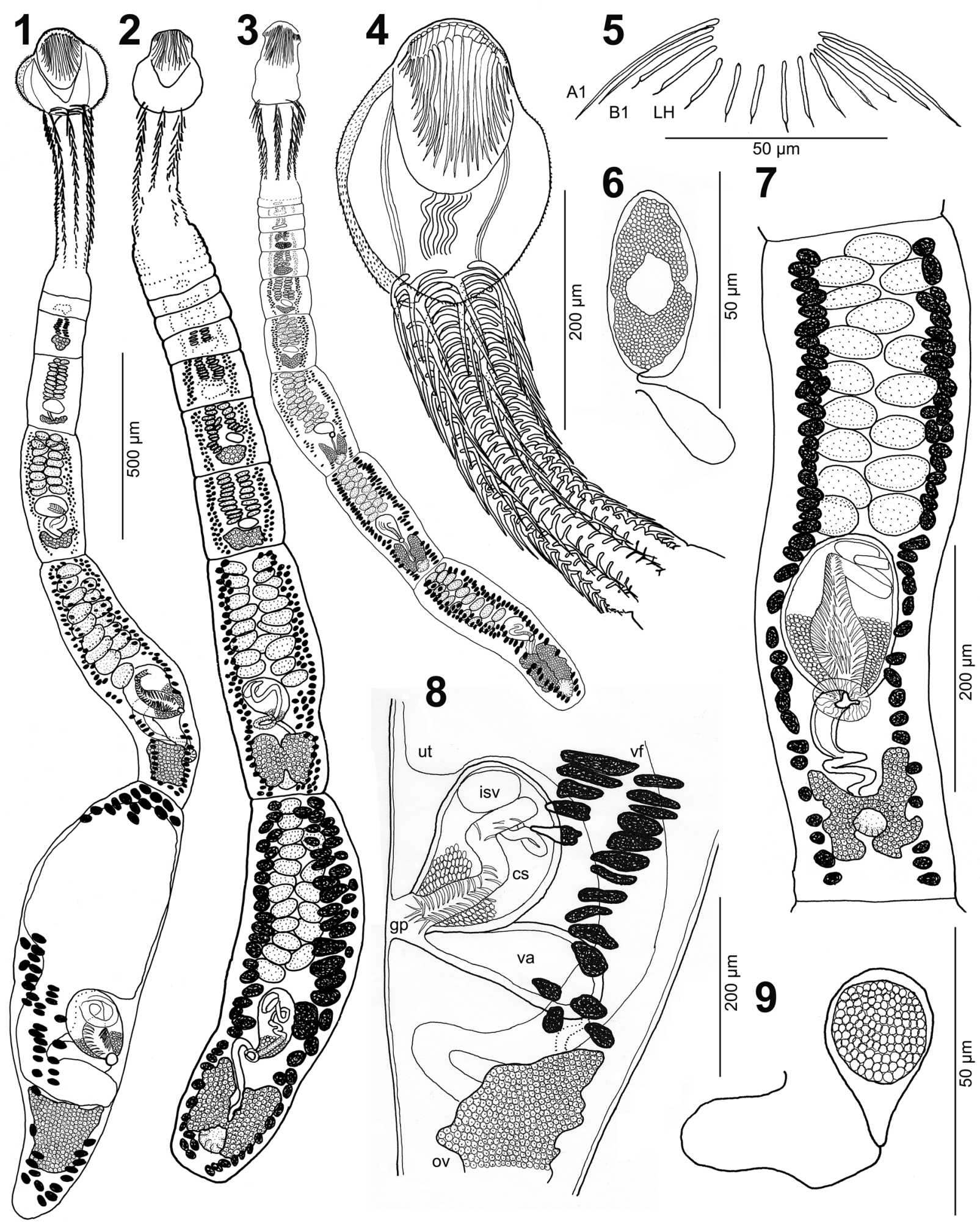

Figs. 1-9. Line drawings. Figs. 1, 4-8. Echinobothrium nataliae sp. n. Fig. 1. Whole worm. Fig. 4. Scolex. Fig. 5. Lateral hooklets. Fig. 6. Egg. Fig. 7. Mature proglottid. Fig. 8. Detail of terminal genitalia, lateral view. Fig. 2. Echinobothrium reginae sp. n., whole worm. Figs. 3, 9. Echinobothrium vojtai sp. n. Fig. 3. Whole worm. Fig. 9. Egg. Abbreviations: A1 - first A (anterior) hook; B1 - first B (posterior) hook; cs - cirrus-sac; gp - genital pore; isv - internal seminal vesicle; LH - lateral hooklets; ov - ovary; ut - uterus; va - vagina; vf - vitelline follicles. 
ing in length posteriorly; free prong of first 3 anterior spines $79-89(84 \pm 3 ; 6)$ long; free prong of last 3 posterior spines 10-25 (18 \pm 5 ; 6) long (Fig. 4).

Distal bothrial surfaces with conspicuous central triangular region; triangular region covered with capilliform and acicular filitriches (Fig. 24); border between central triangular region and remainder of distal surfaces with altering rows of large cilia 2 long (Figs. 23, 24); remainder of distal surfaces covered with trifurcate spinitriches with slender digits (Figs. 23, 24). Proximal bothrial surfaces covered anteriorly with small trifid spinitriches $\sim 1$ long interspersed with acicular filitriches (Fig. 21) and posteriorly with robust pectinate spinitriches $\sim 4$ long with 7-8 digits interspersed with acicular filitriches (Fig. 22). Apex of scolex proper apparently devoid of microtriches. Cephalic peduncle and proglottids covered with capilliform filitriches (Fig. 25).

Immature proglottids $4-5$ in number, initially wider than long, becoming longer than wide with maturity (Fig. 1). Mature proglottids 1-2 in number, 415-748 $(556 \pm 105$; 9) long by $138-288(188 \pm 8 ; 9)$ wide, length:width ratio $1.5-3.5: 1$. Gravid proglottid 1 in number, $764-1,194(1,028 \pm 154 ; 9)$ long by $150-373$ $(245 \pm 66 ; 9)$ wide, length:width ratio $3.0-6.3: 1$. Testes $16-20(18 \pm 1 ; 10)$ in number, $25-46(31 \pm 6 ; 10)$ long by $45-75(63 \pm 9 ; 10)$ wide, arranged in 2 regular columns from anterior margin of proglottid to anterior margin of cirrus-sac, 1 row deep in cross-section (Fig. 7). Cirrus-sac ovoid, 118-213 (168 $\pm 34 ; 10)$ long by $97-242(136 \pm 41$; 10) wide, length:width ratio $1.0-1.5: 1$, located anterior to vagina, containing robust cirrus; cirrus covered with large coniform spinitriches; spinitriches 16-23 (20 \pm 3 ; 7) long (Figs. 7, 8). Internal seminal vesicle 53-71 (66 \pm 7; 7) long by $44-65(52 \pm 8 ; 7)$ wide; external seminal vesicle not seen. Vas deferens minimal. Ovary near posterior margin of proglottid, H-shaped in frontal view (Fig. 7), $86-364(164 \pm 87 ; 10)$ long by $71-163(99 \pm 29 ; 10)$ at widest point, (Fig. 7). Mehlis' gland posterior and dorsal to ovarian isthmus, $28-65(47 \pm 14 ; 10)$ long by $24-53$ $(31 \pm 11 ; 10)$ wide, (Fig. 7). Vagina short, posterior to cirrus-sac, with robust muscular sack-like distal portion opening into genital pore, $45-62(49 \pm 6 ; 10)$ long by $51-$ $108(81 \pm 17 ; 10)$ wide (Fig. 8). Genital pore midventral, $29-45 \%$ (34\%) from posterior margin of mature proglottid; $33-46 \%(36 \%)$ from posterior margin of gravid proglottid. Vitellarium follicular; vitelline follicles 15-29 $(19 \pm 4 ; 10)$ long by $33-69(50 \pm 15 ; 10)$ wide, in 2 lateral fields, distributed throughout length of proglottid, uninterrupted at level of ovary; vitelline fields not confluent in anterior and posterior extremities of proglottid (Fig. 7). Uterus saccate, originating as uterine duct in ootype region, extending anterodorsal to cirrus-sac, ventral to testes (Figs. 1, 8). Eggs oval, 34-39 (36 $\pm 1 ; 10)$ long by 16-17 $(17 \pm 0.5 ; 10)$ wide, with single terminal polar filament; terminal filament 45-50 long (Fig. 6); unembryonated.
Type and only host: Pastinachus solocirostris Last, Manjaji et Yearsley, 2005 (Rajiformes: Dasyatidae).

Type locality: South China Sea, Malaysian Borneo, Sarawak, off Semantan $\left(01^{\circ} 48^{\prime} 15.45^{\prime \prime} \mathrm{N}, 109^{\circ} 46^{\prime} 47.17^{\prime \prime} \mathrm{E}\right)$ (BO-164); May 14, 2003.

Additional loc ality: South China Sea, Malaysian Borneo, Sarawak, off Mukah (02 $\left.53^{\prime} 52^{\prime \prime} \mathrm{N}, 112^{\circ} 05^{\prime} 44^{\prime \prime} \mathrm{E}\right)$.

Site of infection: Spiral intestine.

Prevalence and intensity: 6 of 9 (67\%) examined, infected with 4 to 26 individuals per host; total of 128 diphyllideans.

Specimens deposited: Holotype(MZUM(P) No. 1504) and 2 paratype (MZUM(P) Nos. 1505-1506); 1 paratype (SBC No. P-00030); 7 paratypes (LRP Nos. 7451-7457); 5 paratypes prepared for SEM retained in junior author's collection; 3 paratypes (USNPC Nos. 103001-103002); 4 paratypes (IPCAS No. C-558/1).

Etymology: This species is named in honour of the senior author's niece, Natálie (= Natalia; nataliae) Kuchtová.

Remarks. Echinobothrium nataliae is readily distinguished from all but 10 of the 36 valid species of the genus (Table 1) in its possession of lateral hooklets that are arranged in a continuous band rather than in dorsal and ventral groups, on each side of the scolex. With respect to the other species with lateral hooklets arranged in continuous bands, E. nataliae exhibits a greater number of spines in each cephalic peduncle column than E. californiense, E. hoffmanorum, E. pigmentatum, and E. rayallemangi (24-29 vs. 5-7, 14-16, 8-13, 2-5, per column, respectively) and fewer spines per column than E. euzeti, E. megacanthum, (24-29 vs. 100-107, 38-43, respectively). Echinobothrium nataliae possesses fewer lateral hooklets in a band than E. bonasum, E. fautleyae, and E. raschii (10-14 vs. 24-27, 20-21, 24-36, respectively). Finally, it differs from E. mexicanum in possessing a greater number of anterior and posterior apical hooks (14/13-15 vs. 12/11). Furthermore, E. nataliae, is one of only 5 species of Echinobothrium having remarkably large cirrus spinitriches. In this respect it resembles $E$. bonasum, E. mathiasi, E. megacanthum and E. mexicanum.

Echinobothrium reginae sp. n. Figs. 2, 10-13, 27-33

Description (based on whole mounts of 9 mature worms, 2 compressed scoleces and 2 specimens examined with SEM): Worms euapolytic, 2,716-4,575 (3,245 \pm 604 ; 9) long, greatest width at level of terminal proglottid, 217-337 (270 \pm 41 ; 9) wide; proglottids acraspedote, 12 15 in number (Fig. 2). Scolex consisting of scolex proper and cephalic peduncle (Figs. 10, 27). Scolex proper 176$229(203 \pm 18$; 9) long by 136-189 (153 \pm 18 ; 9) wide, composed of armed apical rostellum and 1 dorsal and 1 ventral bothrium; bothria 102-147 (124 \pm 16 ; 9) long by $130-189(160 \pm 29 ; 2)$ wide. Rostellum bearing 1 dorsal and 1 ventral group of 29 solid apical hooks arranged in 2 rows flanked on each side by single continuous band of 
Kuchta, Caira: Three new Echinobothrium spp. from Pastinachus
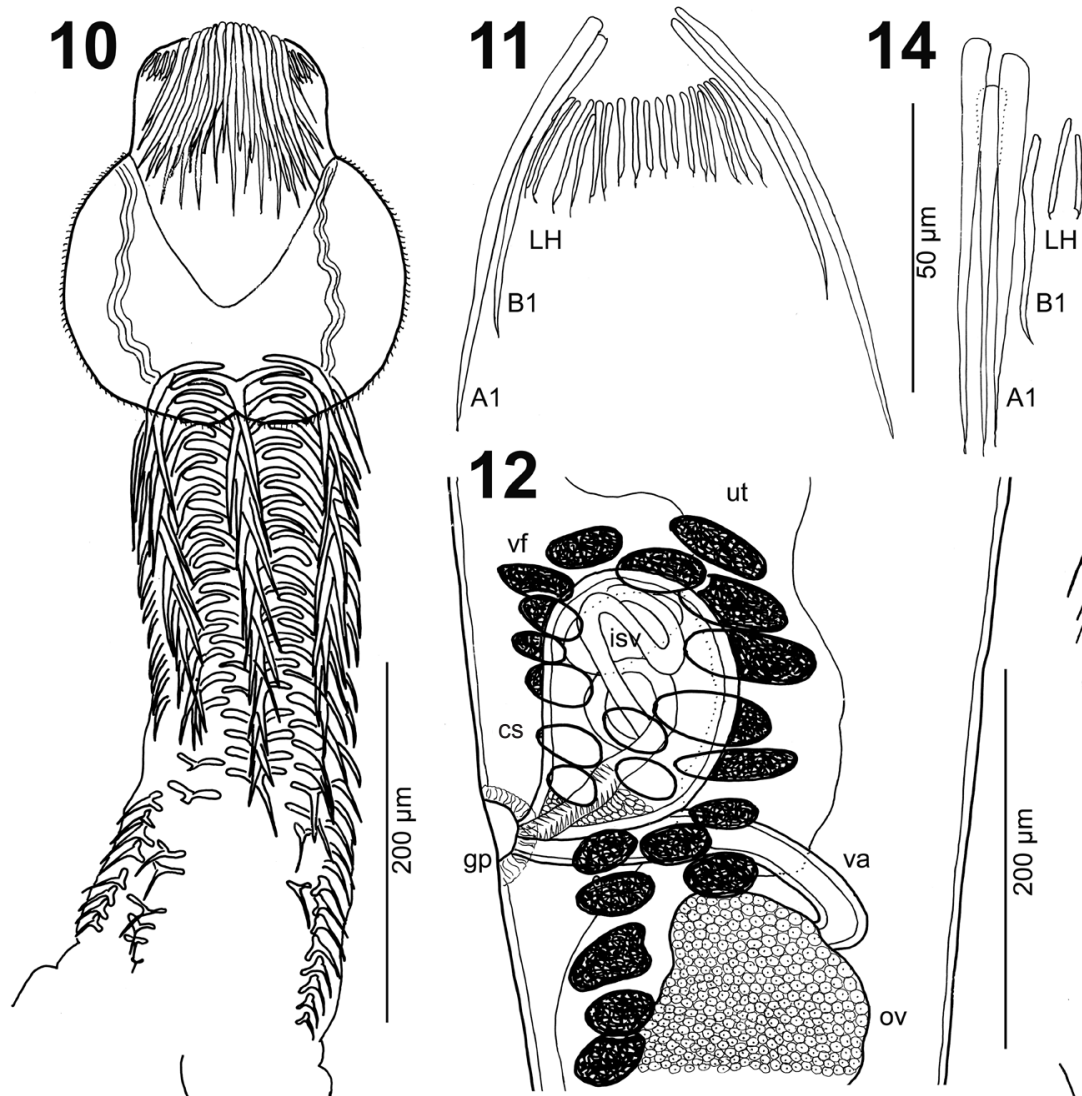

A1

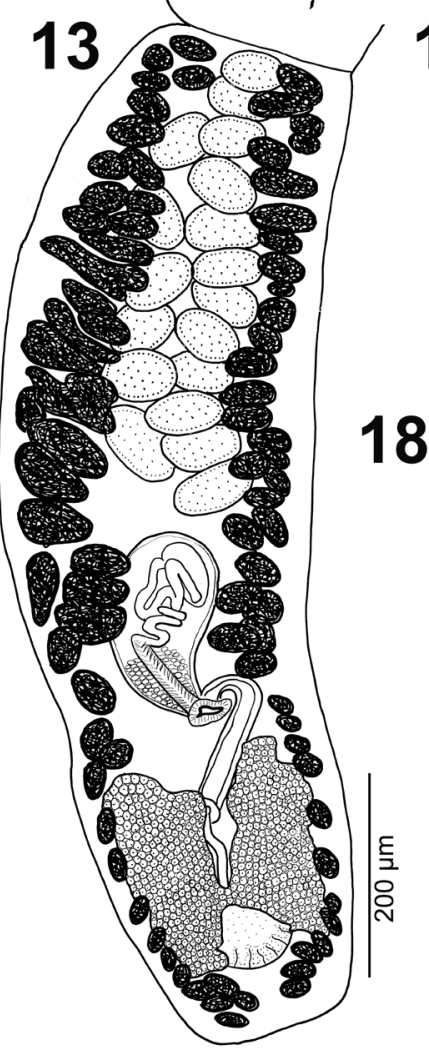

16
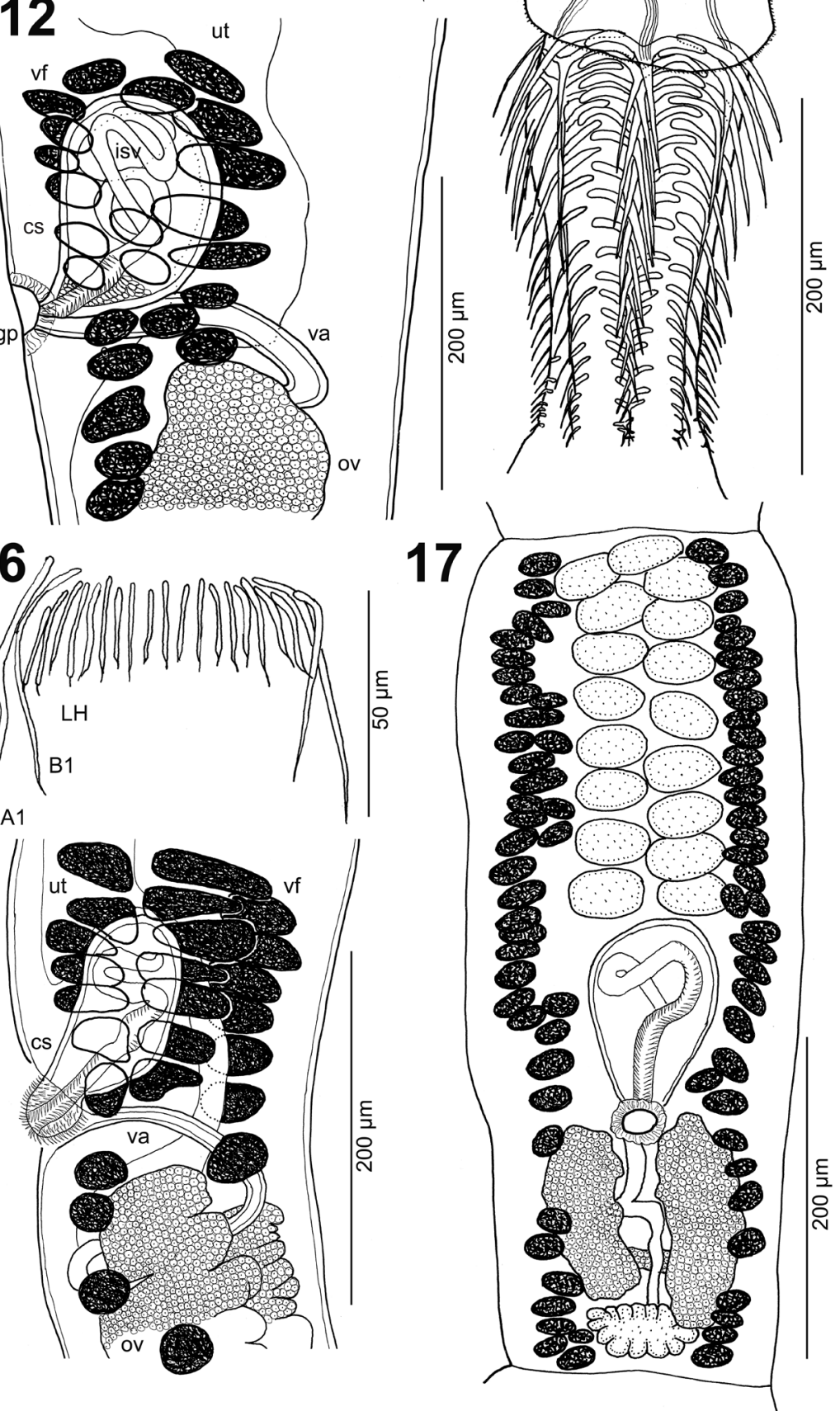

Figs. 10-18. Line drawings. Figs. 10-13. Echinobothrium reginae sp. n. Fig. 14. Echinobothrium fautleyae, detail of lateral-most hooks and hooklets. Figs. 15-18. Echinobothrium vojtai sp. n. Figs. 10, 15. Scolex. Figs. 11, 16. Hooklets. Figs. 12, 18. Detail of terminal genitalia, lateral view. Figs. 13, 17. Mature proglottid. Abbreviations: A1 - first A hook; B1 - first B hook; cs - cirrus-sac; $\mathrm{gp}$ - genital pore; isv - internal seminal vesicle; LH - lateral hooklets; ov - ovary; ut - uterus; va - vagina; vf - vitelline follicles. 
$16-17(16.5 \pm 1 ; 5)$ small lateral hooklets; hooklets $22-30$ $(25 \pm 2 ; 32)$ long, with scalpel-like blade (Figs 10, 11, 27, $28)$. Hook formula $\{(16-17) 14 / 15\}$. Apical hooks gradually increasing in length towards centre of group, type B symmetry. First B hook after hooklets $48-51(50 \pm 2 ; 2)$ long (41-44\% longer than adjacent hooklet), remaining B hooks 75-104 $(93 \pm 9$; 11) long; first A hook after first B hook 83-91 $(86 \pm 4 ; 2)$ long $(42-43 \%$ longer than first B hook), remaining A hooks 97-105 (100 \pm 5 ; 10) long. Cephalic peduncle $300-449(367 \pm 40 ; 9)$ long by $85-125$ $(101 \pm 14 ; 9)$ wide, armed with 8 longitudinal columns of $30-33(32.5 \pm 3 ; 10)$ spines; spines with triradiate bases, decreasing in length posteriorly; free prong of first 3 anterior spines $74-88(82 \pm 5 ; 7)$ long; free prong of last 3 posterior spines 6-27 (18 $\pm 9 ; 7)$ long (Figs. 10, 27).

Distal bothrial surfaces with conspicuous central triangular region; triangular region covered with capilliform filitriches and some acicular filitriches (Fig. 31), remainder of distal surfaces covered with trifurcate spinitriches with slender digits (Fig. 31). Proximal bothrial surfaces covered with small trifid spinitriches $\sim 1.5$ long, interspersed with capilliform filitriches (Figs. 30, 33). Apex of scolex proper surface apparently devoid of microtriches, covered with irregular grooves (Fig. 29). Cephalic peduncle and proglottids covered with capilliform filitriches (Fig. 32).

Immature proglottids $9-13$ in number, initially wider than long, becoming longer than wide with maturity (Fig. 2). Mature proglottids 1-2 in number, 398-801 $(595 \pm 129$; 9) long by $184-308(225 \pm 41$; 9) wide; length:width ratio 2.0-3.4:1. Gravid proglottid 1 in number, 678-1,166 (908 \pm 168 ; 9) long by $220-337$ $(269 \pm 41 ; 9)$ wide, length:width ratio $3.1-3.9: 1$. Testes $17-19(18 \pm 1 ; 9)$ in number, $31-50(34 \pm 7 ; 10)$ long by $54-80(68 \pm 10 ; 10)$ wide, arranged in 2 irregular columns from anterior margin of proglottid to anterior margin of cirrus-sac, 1 row deep in cross-section (Figs. 2, 13). Cirrus-sac pyriform, 96-177 $(140 \pm 3 ; 9)$ long by $54-110$ $(84 \pm 15 ; 9)$ wide, length:width ratio $1.6-2.1: 1$, located anterior to vagina; cirrus covered with small slender spinitriches; cirrus spinitriches 4-7 $(6 \pm 1 ; 10)$ long (Figs. 12, 13). Internal seminal vesicle present, $56-60$ long by $35-40$ wide; external seminal vesicle not seen. Vas deferens minimal. Ovary near posterior margin of proglottid, H-shaped in frontal view (Fig. 13), 100-195 (139 \pm 37 ; 9) long by 80-175 (125 $\pm 32 ; 9)$ wide at widest point, extending to genital pore. Mehlis' gland posterior-dorsal to ovarian isthmus, 42-99 (68 \pm 19 ; 9) long by 47-93 (74 $\pm 13 ; 9)$ wide (Fig. 13). Vagina short, muscular, distal portion not expanded, 19-41 (26 \pm 7 ; 9) in diameter (Figs. 12, 13). Genital pore midventral, 28-38\% (32\%) from posterior margin of mature proglottid, $31-45 \%$ (36\%) from posterior margin of gravid proglottid. Vitellarium follicular; vitelline follicles $14-28(21 \pm 4 ; 10)$ long by $33-60(45 \pm 8$; 10) wide, in 2 lateral fields, distributed throughout length of proglottid, uninterrupted at level of ovary; vitelline follicles confluent or not at anterior and posterior extremities of proglottid (Fig. 13). Uterus saccate, originating as uterine duct in ootype region, extending anterodorsal to cirrus-sac, continuing as expanded sac ventral to testes. Eggs not observed.

Type and only host: Pastinachus cf. sephen (Forsskål, 1775) (Rajiformes: Dasyatidae) (GA-16).

Type locality: La Mer d'Emeraude near Ramena, Madagascar, Indian Ocean $\left(12^{\circ} 11^{\prime} 60^{\prime \prime} \mathrm{S}, 4^{\circ} 22^{\prime} 00^{\prime \prime} \mathrm{E}\right)$; September 20, 1999.

Site of infection: Spiral intestine.

Prevalence and intensity: 1 of 2 examined, infected with 14 individuals.

Specimens deposited: Holotype (MNHN(P) No. HEL 154); 4 paratypes (LRP Nos. 7460-7463); 2 specimens prepared for SEM retained in junior author's collection; 3 paratypes (USNPC Nos. 103003-103005); 4 paratypes (IPCAS No. C-557/1).

Ety mology: This species is named in honour of the senior author's mother, Regina Kuchtová.

Remarks. Echinobothrium reginae differs from all but 11 of the 37 valid species of the genus, including E. nataliae (Table 1), in its possession of lateral hooklets arranged in a continuous band, rather than in distinct dorsal and ventral groups. With respect to the other species with continuous bands of lateral hooklets, it differs from all but $E$. hoffmanorum in number of lateral hooklets; it possesses a greater number of lateral hooklets than E. euzeti, E. megacanthum, E. mexicanum, and E. nataliae (16-17 vs. 13-14, 12, 10-13, 10-14, respectively) and fewer lateral hooklets than $E$. bonasum, E. californiense, E. fautleyae, E. pigmentatum, E. raschii, and E. rayallemangi, (16-17 vs. 24-27, 19-24, 20-21, 20-22, 24-36, 20-24, respectively). Echinobothrium reginae conspicuously differs from $E$. hoffmanorum in number of cephalic peduncle spines in each column; whereas E. reginae bears 30-33 spines per column, E. hoffmanorum has only 14-16.

Echinobothrium vojtai sp. n. Figs. 3, 9, 15-18, 34-40

Description (based on whole mounts of 12 mature worms, 5 compressed scoleces, semi-permanent mount of 1 gravid proglottid in lactophenol and 2 specimens examined with SEM): Worms euapolytic, 1,872-3,059 $(2,607 \pm 322 ; 10)$ long, greatest width at level of terminal proglottid, $217-258(240 \pm 24 ; 10)$ wide; proglottids acraspedote, 10-12 in number (Fig. 3). Scolex consisting of scolex proper and cephalic peduncle (Figs. 15, 34). Scolex proper $178-258(222 \pm 23 ; 10)$ long by $117-160$ $(141 \pm 19 ; 10)$ wide, composed of armed apical rostellum and 1 dorsal and 1 ventral bothrium; bothria 110-171 (139 $\pm 20 ; 10)$ long by $115-137(124 \pm 9 ; 3)$ wide. Rostellum bearing 1 dorsal and 1 ventral group of 29 solid apical hooks arranged in 2 rows flanked on each side by continuous band of $18-20(19 \pm 1 ; 10)$ small lateral hooklets; hooklets $22-32(26.5 \pm 2 ; 36)$ long, with scalpel-like blade (Figs. 16, 35). Hook formula $\{(18-20) 14 / 15\}$. Apical hooks gradually increasing in length towards centre of group, type B symmetry. First B hook after hooklets 


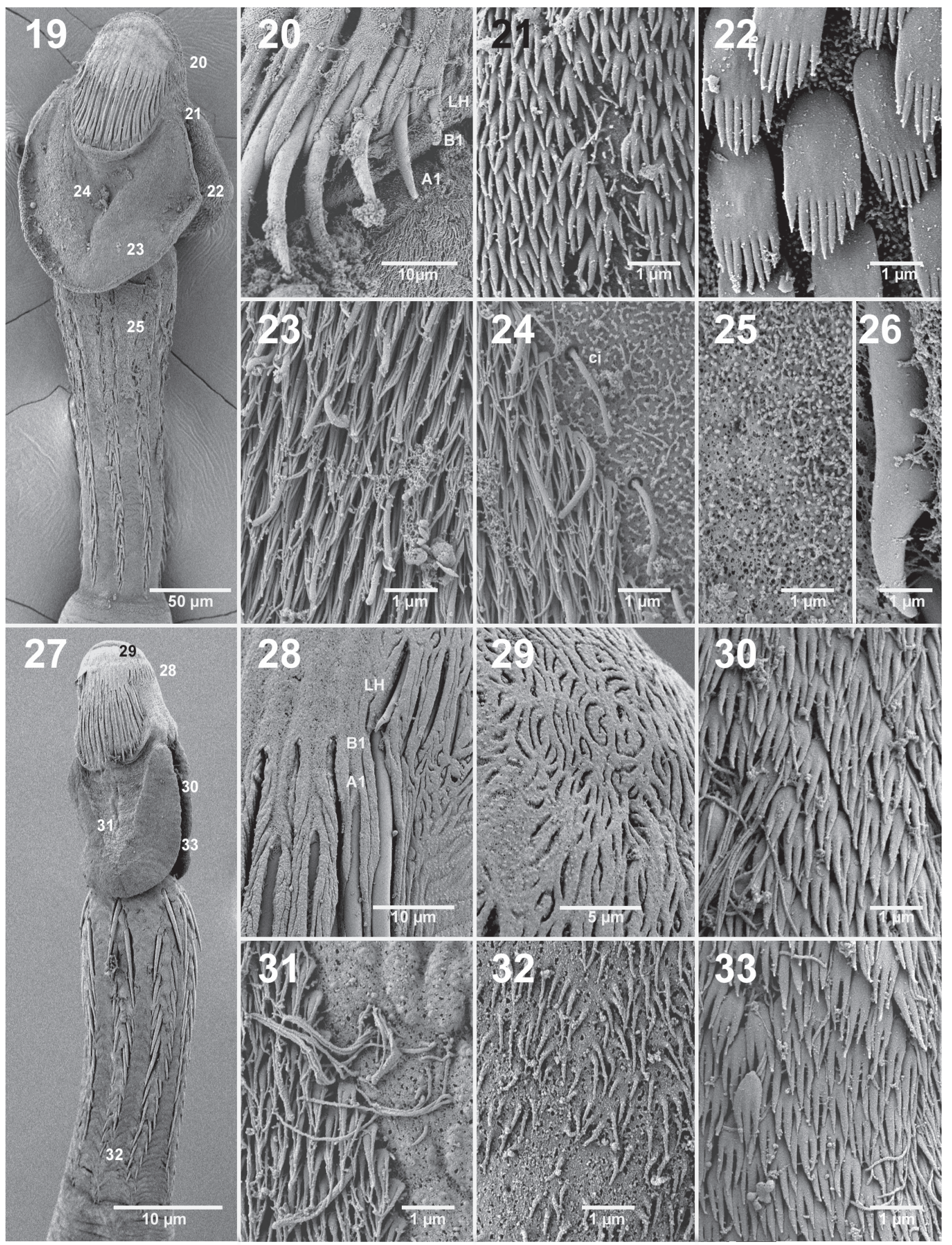

Figs. 19-33. Scanning electron micrographs. Figs. 19-26. Echinobothrium nataliae sp. n. Figs. 19. Scolex. Note: small numbers correspond to the figures showing higher magnification images of these surfaces. Fig. 20. Detail of first apical hooks and lateral hooklets. Fig. 21. Anterior region of proximal bothrial surface. Fig. 22. Posterior region of proximal bothrial surface. Fig. 23. Posterior region of distal bothrial surface. Fig. 24. Distal bothrial surface at margin of central triangular region. Fig. 25. Surface of cephalic peduncle. Fig. 26. Detail of hooklet. Figs. 27-33. Echinobothrium reginae sp. n. Fig. 27. Scolex. Note: small numbers correspond to the figures showing higher magnification images of these surfaces. Fig. 28. Detail of first apical hooks and lateral hooklets. Fig. 29. Surface of apical region of scolex. Fig. 30. Anterior region of proximal bothrial surface. Fig. 31. Distal bothrial surface at margin of central triangular region. Fig. 32. Surface of cephalic peduncle. Fig. 33. Posterior region of proximal bothrial surface. Abbreviations: A1 - first A (anterior) hook; B1 - first B (posterior) hook; ci - cilium; LH - lateral hooklet. 
$48-51(50.5 \pm 2 ; 3)$ long (37-44\% longer than adjacent hooklet), remaining B hooks 72-104 (94 \pm 8 ; 33) long; first A hook after first B hook 72-91 (82 \pm 8 ; 3) long (30$50 \%$ longer than adjacent B hook), remaining A hooks 82 $105(95 \pm 8 ; 31)$ long. Cephalic peduncle short, 181-243 $(208 \pm 18 ; 10)$ long by $68-110(96 \pm 13 ; 10)$ wide, armed with 8 longitudinal columns of 20-26 spines each; spines with triradiate bases, decreasing in length posteriorly; free prongs of first 3 anterior spines $62-75$ (70 \pm 3 ; 10) long; free prongs of last 3 posterior spines $7-12(11 \pm 2 ; 10)$ long (Figs. 15, 34).

Distal bothrial surfaces with conspicuous central triangular region; triangular region covered with capilliform filitriches (Fig. 37), remainder of distal surfaces covered with trifurcate spinitriches with slender digits (Fig. 38). Proximal bothrial surfaces covered with small trifid spinitriches $\sim 1.5$ long (Fig. 36), interspersed with capilliform filitriches. Apex of scolex proper surface apparently devoid of microtriches, covered with grooves. Cephalic peduncle (Fig. 39) and proglottids (Fig. 40) covered with capilliform filitriches,

Immature proglottids 7-9 in number, initially wider than long, becoming longer than wide with maturity (Fig. 3). Mature proglottids $1-2$ in number, 429-598 (517 \pm 56 ; 10) long by $177-282(212 \pm 28 ; 10)$ wide; length:width ratio 2.1-2.9:1. Gravid proglottid 1 in number, 660 $736(709 \pm 27 ; 5)$ long by $217-278(240 \pm 22 ; 5)$ wide; length:width ratio $2.6-3.3: 1$. Testes $16-18(17 \pm 1 ; 7)$ in number, $40-69(54 \pm 8 ; 10)$ long by $22-47(32 \pm 8 ; 10)$ wide, arranged in 2 regular columns from anterior margin of proglottid to anterior margin of cirrus-sac, 1 row deep in cross-section (Fig. 17). Cirrus-sac pyriform, 85-122 $(110 \pm 12 ; 9)$ long by $61-84(71 \pm 7 ; 9)$ wide, length:width ratio $1.3-2.0: 1$, located anterior to lobes of ovary; cirrus covered with small slender spinitriches; cirrus spinitriches 5-7 $(6 \pm 1 ; 7)$ long (Figs. 17, 18). Internal and external seminal vesicles not seen. Vas deferens minimal. Ovary near posterior margin of proglottid, $\mathrm{H}$-shaped in frontal view (Fig. 17), 101-203 (147 $\pm 37 ; 10)$ long by 101-158 $(121 \pm 21 ; 10)$ wide at widest point, extending to genital pore. Mehlis' gland posterior-dorsal to ovarian isthmus, $52-66(60 \pm 6 ; 5)$ long by $36-77(52 \pm 17 ; 5)$ wide (Fig. 17). Vagina short, posterior to cirrus-sac, muscular, 8-24 $(14 \pm 4 ; 9)$ in diameter (Figs. 17, 18). Genital pore midventral, 30-58\% (41\%) from posterior margin of mature proglottid, $29-40 \%$ (35\%) from posterior margin of gravid proglottid. Vitellarium follicular; vitelline follicles $13-22(17 \pm 3 ; 10)$ long by $21-53(41 \pm 11 ; 10)$ wide, in 2 lateral fields, distributed throughout length of proglottid, uninterrupted at level of ovary; vitelline fields not confluent in anterior or posterior extremities of proglottid (Fig. 17). Uterus saccate, originating as uterine duct in ootype region, extending anterodorsal to cirrus-sac, continuing as expanded sac ventral to testes. Eggs (Fig. 9) pyriform, 32-37 (34 $\pm 2 ; 10)$ long by $16-22(20 \pm 2 ; 10)$ wide, with single terminal polar filament on one pole, 45-57 long (Fig. 9); unembryonated.

Type and only host: Pastinachus sp. (thin-tail) (Rajiformes: Dasyatidae) (KA-162).

Type locality: Java Sea, Kalimantan, Selakau $\left(01^{\circ} 03^{\prime} 30.60^{\prime \prime} \mathrm{N}, 108^{\circ} 58^{\prime} 24.60^{\prime \prime} \mathrm{E}\right)$; November 7, 2007.

Site of infection: Spiral intestine.

Prevalence and intensity: 1 of 2 examined, infected with 20 diphyllideans.

Specimens deposited: Holotype (MZB No. Ca 135) and 1 paratype (MZB No. Ca 136); 4 paratypes (LRP Nos. 7464-7467); 5 paratypes prepared for SEM retained in junior author's collection; 3 paratypes (USNPC Nos. 103006 103008); 4 paratypes (IPCAS No. C-556/1).

Etymology: This species is named in honour of the senior author's nephew, Vojtěch (= Vojta; vojtai) Kuchta.

Remarks. Echinobothrium vojtai is easily distinguished from all but 12 of the 38 valid species of the genus, including E. nataliae and E. reginae (Table 1 ) in its possession of lateral hooklets arranged in a continuous band, rather than in dorsal and ventral groups on each side of the scolex. Among the species with continuous bands of lateral hooklets on each side, it has fewer cephalic peduncle spines per column than E. euzeti, E. megacanthum, and E. reginae (20-26 vs. 100-107, 38-43, 30-33, respectively) and a greater number of cephalic peduncle spines per column than E. californiense, E. hoffmanorum, E. pigmentum, and E. rayallemangi (20-26 vs. 5-7, 14-16, 8-13, 2-5, respectively). Furthermore, it bears fewer lateral hooklets per band than E. bonasum, E. raschii (18-20 vs. 24-27, 24-36), a greater number of lateral hooklets per band than E. mexicanum, E. nataliae (18-20 vs. 10-13, 10-14), and a greater number of apical hooks than E. fautleyae (14/15 vs. 6/7).

\section{DISCUSSION}

The diphyllideans are a relatively small order of elasmobranch tapeworms. The taxonomy of the order emphasizes the morphology of the armature of the scolex. In an attempt to facilitate comparisons among diphyllidean species, Neifar et al. (2001) suggested a standardized formula for representing the number and arrangement of rostellar hooks and hooklets. In that system, the armature of the rostellum is considered to consist of two groups of large apical hooks (dorsal and ventral), which may or may not be flanked on each side by smaller lateral hooklets. Jones and Beveridge (2001) proposed that the anterior apical hooks in both the dorsal and ventral groups be assigned the designation $\mathrm{A}$ and the posterior apical hooks in the dorsal and ventral groups be assigned the designation B. Based on the assumption that the apical hooks of the dorsal and ventral faces of the bothria are symmetrical, the formula of Neifar et al. (2001) is as follows: $\{\mathrm{LH} \mathrm{AH(A)/}$ $\mathrm{AH}(\mathrm{B}) \mathrm{LH}\}$, where $\mathrm{AH}(\mathrm{A})$ is the number of type $\mathrm{A}$ apical 

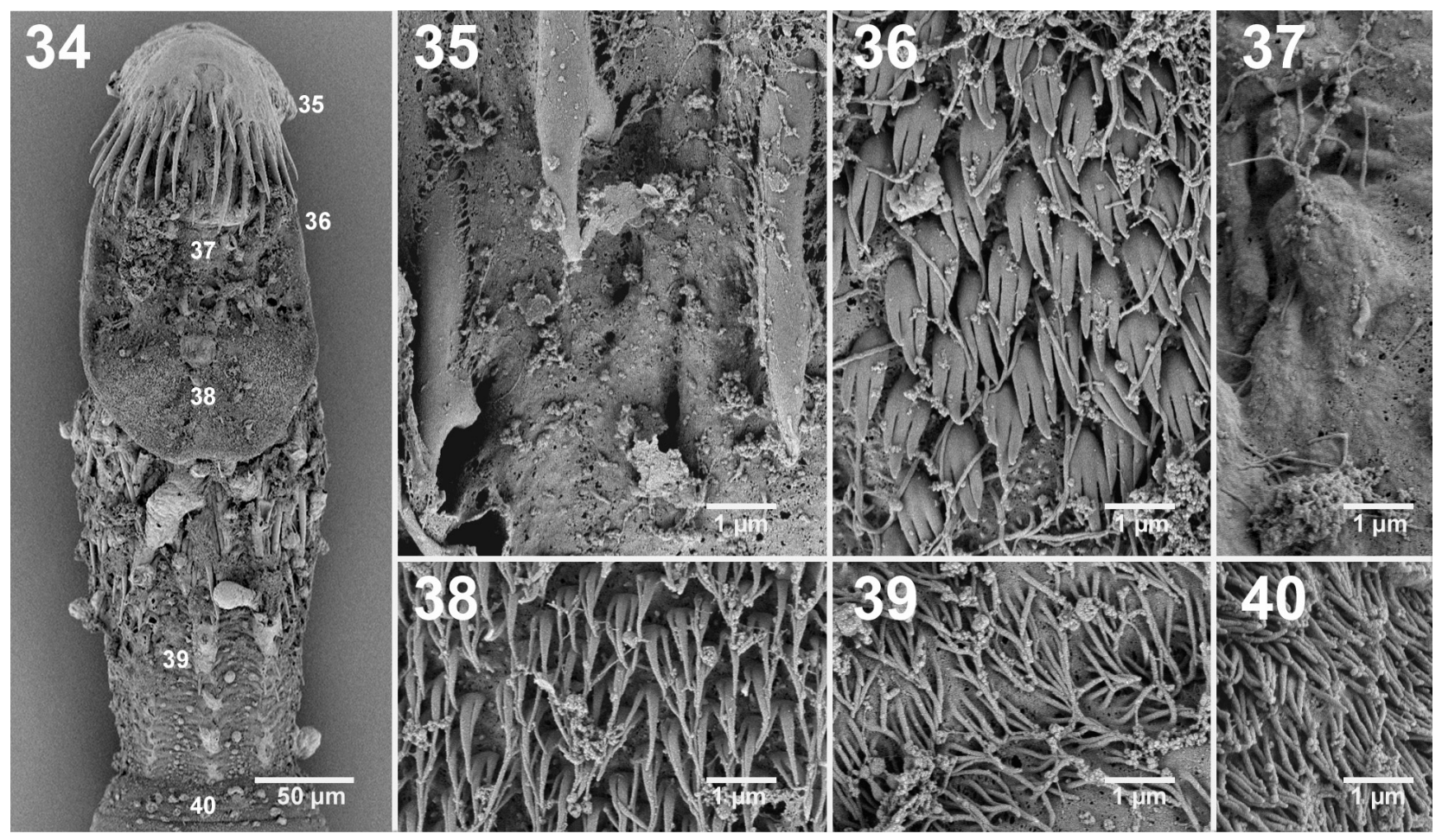

Figs. 34-40. Scanning electron micrographs of Echinobothrium vojtai sp. n. Fig. 34. Scolex. Note: small numbers correspond to the figures showing higher magnification images of these surfaces. Fig. 35. Detail of hooklets. Fig. 36. Proximal bothrial surface. Fig. 37. Distal bothrial surface at margin of central triangular region. Fig. 38. Posterior regions of distal bothrial surface. Fig. 39. Surface of cephalic peduncle. Fig. 40. Surface of proliferation zone.

hooks on a bothrial face, $\mathrm{AH}(\mathrm{B})$ is the number of type $\mathrm{B}$ apical hooks on a bothrial face, and LH is the number of lateral hooklets flanking the apical hooks on each side. In species in which the apical hooks clearly differ from the lateral hooklets in size and/or form, and the lateral hooklets on each side are arranged in distinct dorsal and ventral groups, this formula can be applied without ambiguity. However, when one or both of these conditions is violated, application of the formula can be somewhat problematic.

Additional criteria are required in instances in which size and form make the distinction between apical hooks and lateral hooklets unclear, particularly at the point of transition between the smaller apical hooks and lateral hooklets. For example, in E. fautleyae, there exist armature elements at the boundary between those that are clearly hooks and those that are hooklets that are difficult to classify as either armature type for they are conspicuously smaller than the hooks, but larger than the hooklets (Fig. 14). Tyler and Caira (1999), not without some trepidation, ultimately considered these to be lateral hooklets. However, it now seems clear that the distinction between apical hooks and lateral hooklets should be defined as suggested by Rees (1961), who proposed that elements bearing distal scalpel-like blade should be considered hooklets. Although the hooklets of some species may not have scalpel-like blade, this criterion is useful in the cases of taxa with hooklet that do. Using this criterion, given that the elements of concern in E. fautleyae lack distal scalpel-like blade, these elements are more appropriately considered to represent apical hooks than lateral hooklets. This species is herein redescribed to consist of 6-7, rather than 5-6, apical hooks in a group, with only $10-11$, rather than 11-12, lateral hooklets (see Table 1).

Here we propose a modification of the formula of Neifar et al. (2001) to more readily accommodate taxa bearing lateral hooklets that are arranged in a continuous band between the dorsal and ventral sets of apical hooks on each side (e.g., Figs. 5, 11, 16). For in such taxa, it is difficult to distinguish between the hooklets associated with the dorsal and ventral groups of apical hooks without ambiguity. Tyler (2006) suggested that in such instances, the number expressed in the armature formula as LH should be half that found in the entire band of hooklets on each side. While this solution at least partially addresses the issue, the uninterrupted nature of the band of lateral hooklets is not clearly described. We propose that the total number of hooklets in a band on a side should be presented as a single number (or range if appropriate) in parentheses to mark that it represents the total number of hooklets in one band. This number should precede the apical hook numbers in the formula. Thus, the hook formula would be as follows: $\{(\mathrm{LH}) \mathrm{AH}(\mathrm{A}) / \mathrm{AH}(\mathrm{B})\}$. We have employed this new formula in the descriptions of each of the new species 


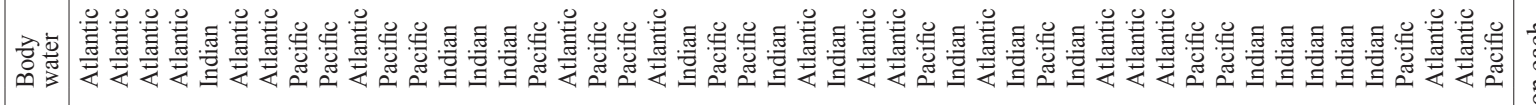

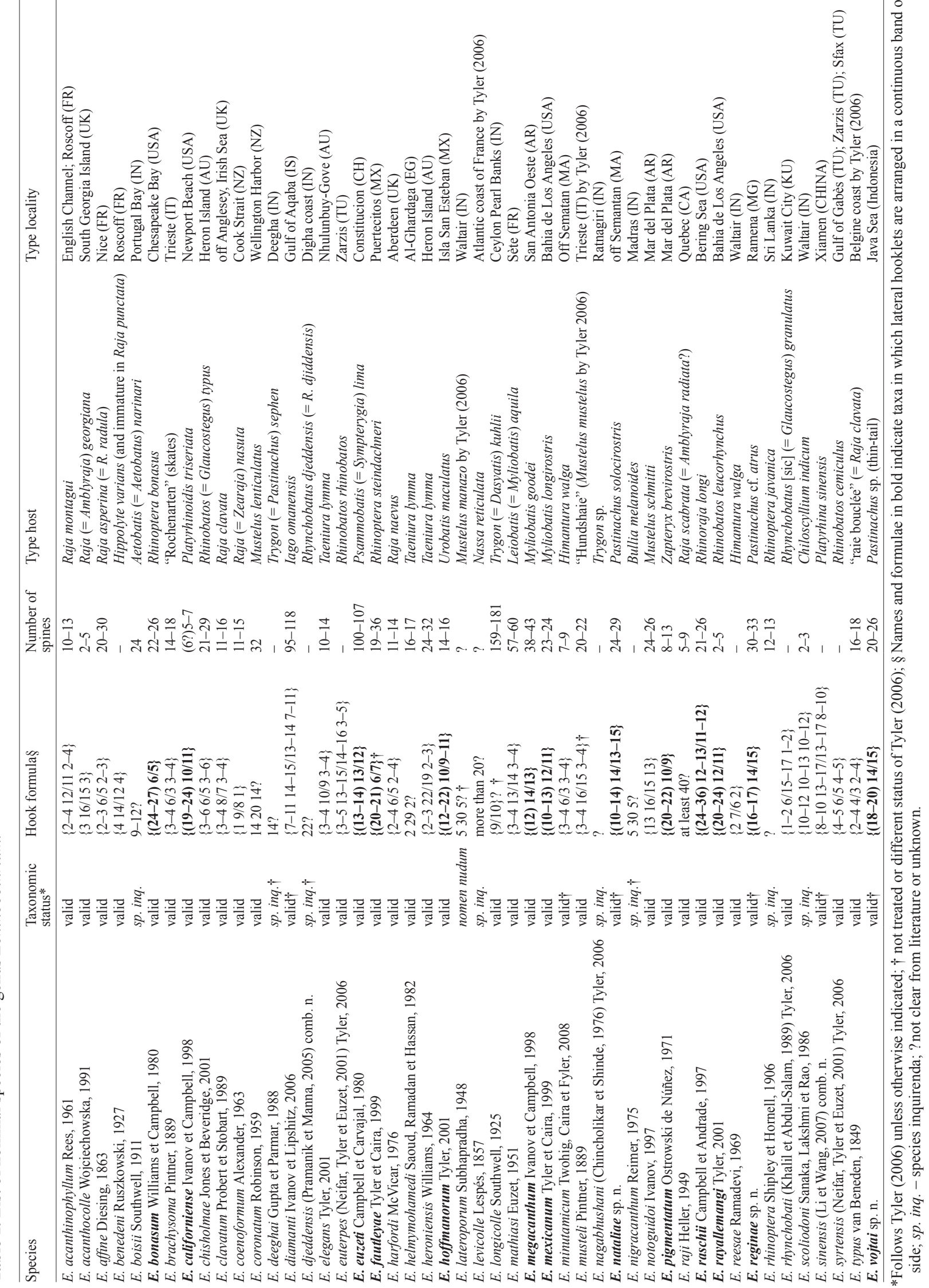


described above, all three of which exhibit lateral hooklets arranged in a continuous band. In order to facilitate interspecific comparisons, the rostellar armature formulae of the nominal species of Echinobothrium for which these data are available are presented in Table 1. In the cases of species that bear a continuous band of lateral hooklets on each side, the formula presented has been modified from that of the original description (and/or that of Tyler, 2006) to conform to the modified version of the formula proposed here; these are indicated in bold in Table 1.

It is interesting to place the hosts of the three new species described here into a broader perspective relative to the hosts of other species of Echinobothrium for our results formally expand the range of host genera known to host diphyllideans. All three of the new diphyllidean species described here were found to parasitize stingrays of the genus Pastinachus. Although previously considered to be monotypic, including only $P$. sephen (Forsskål) from the Red Sea, Pastinachus has recently been determined to include additional species. For example, Last et al. (2005) described Pastinachus solocirostris Last, Manjani et Yearsley from a diversity of localities in the Indo-Pacific, and Last and Stevens (2009) formally recognized Pastinachus atrus (Macleay) from Australia. Although Echinobothrium nataliae was described from one of these newly recognized cowtail species, both $E$. reginae and $E$. vojtai were hosted by potentially undescribed species of Pastinachus (see http://tapewormdb.uconn.edu/hosts.php). The host of $E$. vojtai represents a second species from Borneo bearing a shallow ventral fin-fold. Given that this species has not yet been described, it has been referred to here as Pastinachus sp. (thin-tail). The identity of the host of E. reginae is potentially even more problematic. This host specimen (GA-16) was also found to host Uncibilocularis loreni Jensen et Caira, 2008 by Jensen and Caira (2008). The issues associated with the identity of this animal were discussed by Jensen and Caira (2008), who presented a figure (fig. 46) in the hopes that this would aid in the ultimate identification of this specimen once the taxonomy of Pastinachus is better understood. Given that it bears a well-developed ventral fin fold, we recognize that this specimen may ultimately be determined to be $P$. sephen. However, in the absence of detailed taxonomic work on the cowtail stingrays of Madagascar, for consistency sake, we will follow Jensen and Caira (2008) and continue to refer to this specimen as $P$. cf. sephen.

To date, only a single other species of Echinobothrium has potentially been described from a species of Pastinachus. This species, Echinobothrium deeghai Gupta et Parmar, 1988, was described from Trygon sephen [sic] from the coast of India. Unfortunately, the description of Gupta and Parmar (1988) is superficial and the illustrations are schematic. No hook formula is presented and the description and illustrations suggest that the species not only lacks cephalic peduncle spines, but also lacks lateral hooklets. Perhaps most importantly, no mention is made of type material in the original description. Given these deficiencies, despite its recognition as a valid species by Tyler (2006), we concur with Campbell and Andrade (1997) that this species should be considered a species inquirenda.

Our results suggest that species of Pastinachus are viable hosts of Echinobothrium species. It seems likely that species of Pastinachus that have not yet been examined for tapeworms will be found to also serve as hosts for this diphyllidean genus. Furthermore, our results suggest that Echinobothrium is more globally widespread than previously thought.

Acknowledgements. We thank Kirsten Jensen and Loren Caira for assisting with the collection of hosts and Peter Last for providing expert advice on the identification of the host specimens examined here. Dr. Sylve're Rakotofiringa, Directeur de la Recherche Ministe're de l'Enseignement Supérieur, kindly arranged permission for JNC to remove the tapeworm specimens from Madagascar for study. Collections in Sarawak were conducted under collecting permit No. UPE:40/200/19SJ.924 from the Economic Planning unit in Kuala Lumpur and research agreement No. SBC-RA-0050-JNC from the Sarawak Biodiversity Center in Kuching. This work was supported in part with funds from NSF Nos. DEB 011882, DEB 0542846, DEB 0542941, DEB 0818696, and DEB 0818823 as well as the Grant Agency of the Academy of Sciences of the Czech Republic (project No. KJB600960602), Grant Agency of the Czech Republic (project No. P506/10/1994), the Institute of Parasitology (Z60220518 and LC522), the Faculty of Science, University of South Bohemia (MSM 6007665801), as well as a Fulbright post-doc award to RK (No. 2008-21-03).

\section{REFERENCES}

Campbell R.A., Andrade M. 1997: Echinobothrium raschii n. sp. (Cestoda: Diphyllidea) from Rhinoraja longi (Chondrichthyes, Rajoidei) in the Bering Sea. J. Parasitol. 83: 115-120.

Chervy L. 2009: Unified terminology for cestode microtriches: a proposal from the International Workshops on Cestode Systematics in 2002-2008. Folia Parasitol. 56: 199-230.

Gupta V., Parmar S. 1988: Echinobothrium deeghai sp. n. from a marine fish Trygon sephen of West Bengal. Proc. Parasitol. 6: $78-81$.
Ivanov V.A., Lipshitz A. 2006: Description of a new diphyllidean parasite of triakid sharks from the deep Red Sea. J. Parasitol. 92: 841-846.

Jensen K. 2005: A Monograph on the Lecanicephalidea (Platyhelminthes, Cestoda). Tapeworms of Elasmobranchs Part I. University of Nebraska State Museum, Lincoln, Nebraska, $241 \mathrm{pp}$.

Jensen K., Caira J.N. 2008: A revision of Uncibilocularis Southwell, 1925 (Tetraphyllidea: Onchobothriidae) with the description of four new species. Comp. Parasitol. 75: 157-173. 
Jones M.K., Beveridge I. 2001: Echinobothrium chisholmae n. sp. (Cestoda, Diphyllidea) from the giant shovel-nose ray Rhinobatos typus from Australia, with observations on the ultrastructure of its scolex musculature and peduncular spines. Syst. Parasitol. 50: 41-52.

Last P.R., Manjaji B.M., Yearsley G.K. 2005: Pastinachus solocirostris sp. nov., a new species of stingray (Elasmobranchii: Myliobatiformes) from the Indo-Malay Archipelago. Zootaxa 1040: 1-16.

Last P.R., Stevens J.D. 2009: Sharks and Rays of Australia. Second Edition. CSIRO Publishing, Collingwood Victoria, Australia, $644 \mathrm{pp}$.

Li H., Wang Y. 2007: A new species of Macrobothriidae (Cestoda: Diphyllidea) from thornback ray Platyrhina sinensis in China. J. Parasitol. 93: 897-900.

Neifar L., Tyler G.A., Euzet L. 2001: Two new species of Macrobothridium (Cestoda: Diphyllidea) from rhinobatid elasmobranchs in the Gulf of Gabès, Tunisia, with notes on the status of the genus. J. Parasitol. 87: 673-680.

Olson P.D., Caira J.N., Jensen K., Overstreet R.M., Palm H.W., Beveridge I. 2010: Evolution of the trypanorhynch ta-

Received 19 November 2009 peworms: parasite phylogeny supports independent lineages of sharks and rays. Int. J. Parasitol. 40: 223-242.

Palm H.W., Waeschenbach A., Olson P.D., Littlewood D.T.J. 2009: Molecular phylogeny and evolution of the Trypanorhyncha Diesing, 1863 (Platyhelminthes: Cestoda). Mol. Phylogenet. Evol. 52: 351-367.

Pramanik P.B., Manna B. 2005: Macrobothridium djeddensis new species (Cestoda: Macrobothridiidae) from Rhynchobatus djeddensis Forsskal, 1775 from Bay of Bengal, at Digha Coast, India. Panjab Univ. Res. J. (Sci.), N. S., 55: 197-200.

ReEs G. 1961: Studies on the functional morphology of the scolex and of the genitalia in Echinobothrium brachysoma Pintner and E. affine Diesing from Raja clavata. Parasitology 51: 193-226.

Tyler G.A. 2006: A Monograph on the Diphyllidea (Platyhelminthes, Cestoda). Tapeworms of Elasmobranchs. Part II. University of Nebraska State Museum, Lincoln, Nebraska, 142 $\mathrm{pp}$

Tyler G.A., Caira J.N. 1999: Two new species of Echinobothrium (Cestoda: Diphyllidea) from myliobatiform elasmobranchs in the Gulf of California, México. J. Parasitol. 85: 327-335.

Accepted 8 March 2010 